\title{
Ophthalmic Manifestations of HIV in the Highly Active Antiretroviral Therapy Era
}

L Mowatt ${ }^{1,2}$

\begin{abstract}
HIV-related eye disease can be classified as retinal HIV microangiopathy, opportunistic infections, neuro-ophthalmic manifestations and unusual malignancies. There is a 52-100\% lifetime accumulative risk of HIV patients developing eye problems. Seventy-seven per cent of patients with ocular manifestations of HIV had CD4 counts $<200$ cells/ $\mu$ L. Cytomegalovirus (CMV) is the most prevalent opportunistic infection, however, Africa has a low incidence of this, and more commonly squamous cell carcinoma, compared to the western hemisphere. Due to highly active antiretroviral therapy (HAART), the anti-CMV therapy may be discontinued if the $C D 4^{+} T$ cell count is $>100$ cells $/ \mu L$ for a minimum of three months. Despite HAART, patients with a CD4 count $<50$ cells/ $\mu L$ have a similar risk of developing CMV retinitis as compared to the pre-HAART era. Opportunistic infections include CMV, herpetic retinopathy (progressive outer retinal necrosis - PORN), less commonly toxoplasmosis, pneumocystis and cryptococcus. Malignancies associated with HIV include Kaposi's sarcoma and conjunctival squamous cell carcinoma. Cranial nerve palsies, optic disc swelling and atrophy are characteristic neuro-ophthalmic features. They usually occur secondary to meningitis/encephalitis (from cryptococcus and tuberculosis). With the advent of HAART, new complications have developed in CMV retinitis: immune recovery uveitis (IRU) and cystoid macula oedema (CMO). Immune recovery uveitis occurs in $71 \%$ of patients if HAART is started before the induction of the anti-CMV treatment. However, this is reduced to $31 \%$ if HAART is started after the induction treatment. Molluscum contagiosum and Kaposi's sarcoma can spontaneously resolve on HAART. Highly active anti-retroviral therapy has reduced the frequencies of opportunistic infections and improved the remission duration in HIV patients.
\end{abstract}

Keywords: Cytomegalovirus retinitis, HAART, HIV, opportunistic infections

\section{Manifestaciones Oftálmicas del VIH en la Era de la Terapia Antiretroviral Altamente Activa}

\author{
L Mowatt ${ }^{1,2}$
}

\begin{abstract}
RESUMEN
Las enfermedades oculares relacionadas con el VIH pueden clasificarse como microangiopatía retiniana por VIH, infecciones oportunistas, manifestaciones neuro-oftálmicas, y tumores inusuales. Hay un riesgo acumulativo de por vida de $52-100 \%$ de que los pacientes con VIH desarrollen problemas oculares. Setenta y siete por ciento de los pacientes con manifestaciones oculares por VIH tenían conteos de CD4 $<200$ células/ $\mu \mathrm{L}$. El citomegalovirus $(C M V)$ es la infección oportunista más frecuente. Sin embargo, África tiene una baja incidencia de CVM, siendo en cambio más común el carcinoma de células escamosas, en comparación con el hemisferio occidental. Debido a la terapia antiretroviral altamente activa (TAAA), la terapia anti-CMV puede suspenderse si el conteo de células $C D 4+T$ es $>100$ células/ $\mu L$ por un mínimo de tres meses. A pesar de la terapia TAAA, los pacientes con un conteo de CD4 $<50$ células/ $\mu L$ tienen un riesgo similar de desarrollar retinitis por CMV en comparación con la era pre-TAAA. Las infecciones oportunistas incluyen CMV, retinopatía herpética (necrosis retiniana progresiva externa - PORN), y menos comúnmente toxoplasmosis, pneumocistosis, y cryptococcus. Los tumores malignos asociados con el VIH incluyen el sarcoma de Kaposi y el carcinoma de células escamosas de conjuntiva. La parálisis del nervio craneal, la inflamación del disco
\end{abstract}

From: ${ }^{1}$ Department of Surgery, Radiology, Anaesthesia and Intensive Care, The University of the West Indies and ${ }^{2}$ University Hospital of the West Indies, Kingston 7, Jamaica, West Indies.
Correspondence: Dr L Mowatt, Department of Surgery, Radiology, Anaesthesia and Intensive Care, The University of the West Indies, Kingston 7, Jamaica, West Indies. E-mail: Lizettemowatt@yahoo.com 
óptico, así como la atrofia, son características neuro-oftálmicas típicas. Generalmente se presentan de forma secundaria en los casos de meningitis, encefalitis (cryptococcus y tuberculosis). Con el advenimiento de TAAA, se han desarrollado nuevas complicaciones de la retinitis por CMV, a saber, la uveitis por recuperación inmunológica (IRU por su sigla en inglés) y el edema macular cistoide (EMC). La uveitis por recuperación inmunológica ocurre en $71 \%$ de los pacientes si la terapia TAAA se comienza antes de la inducción del tratamiento anti-CMV. Sin embargo, esta cantidad se reduce a un $31 \%$ si TAAA se inicia después del tratamiento de inducción. El molusco contagioso y el sarcoma de Kaposi pueden desaparecer espontáneamente con el TAAA. La terapia anti-retroviral altamente activa ha reducido las frecuencias de las infecciones oportunistas, y mejorado la duración de la remisión en pacientes con VIH.

Palabras claves: Retinitis por citomegalovirus, VIH, TAAA, infecciones oportunistas

West Indian Med J 2013; 62 (4): 306

\section{INTRODUCTION}

Ocular features of AIDS were first reported in 1983 (1). Through the early work of Holland and associates, the features of HIV retinopathy, opportunistic infections and Kaposi's sarcoma were first described (1-3). HIV patients have a $52-100 \%$ lifetime accumulative risk of getting ocular involvement (4). Seventy-seven per cent of patients with ocular manifestations of HIV had CD4 counts $<200$ cells $/ \mu \mathrm{L}$ $(5,6)$. The incidence and type of ophthalmic manifestations of HIV varies worldwide (5-11). The effect of HIV on the eye can be classified into retinal microangiopathy, opportunistic infections, neuro-ophthalmic problems and unusual malignancies [Table 1] (7-12).
19). In HAART-naïve patients, the odds ratio of HIV eye problems was 6.3 for $\mathrm{CD} 4$ count $\leq 100$ cells $/ \mu \mathrm{L}$ and 1.3 for CD4 count 101-200 cells/ $\mu$ l. The CD4 count and WHO clinical stage are important predictors of the presence of HIV-related eye disease (19). The incidence of ocular complications since HAART is $26.3-50 \%(8,20,21)$. The role of the ophthalmologist cannot be underestimated in the management of HIV patients.

\section{Retinal microangiopathy}

HIV retinal microangiopathy is characterized by intraretinal haemorrhages with cotton wool spots (white ill-defined retinal lesions indicating retinal ischaemia), but does not cause

Table: Main ocular manifestations of HIV/AIDS

\begin{tabular}{|c|c|c|c|c|}
\hline $\begin{array}{l}\text { Opportunistic } \\
\text { infections }\end{array}$ & $\begin{array}{l}\text { Neuro-ophthalmic } \\
\text { manifestations }\end{array}$ & $\begin{array}{l}\text { Unusual } \\
\text { malignancies }\end{array}$ & $\begin{array}{c}\text { Retinal } \\
\text { vasculopathy }\end{array}$ & $\begin{array}{c}\text { Ocular } \\
\text { complications }\end{array}$ \\
\hline $\begin{array}{l}\text { Cytomegalovirus } \\
\text { Herpetic } \\
\text { (PORN) } \\
\text { Toxoplasmosis } \\
\text { Pneumocystis } \\
\text { Syphilis } \\
\text { Mycobacteria } \\
\text { Cryptosporidium } \\
\text { Microsporidia }\end{array}$ & $\begin{array}{l}\text { Extra ocular motility } \\
\text { disorders } \\
\text { Optic disc swelling } \\
\text { Optic atrophy } \\
\text { Visual field defects } \\
\text { secondary to } \\
\text { cryptococcal, } \\
\text { tuberculous, syphilitic } \\
\text { meningitis, } \\
\text { Central nervous system } \\
\text { toxoplasmosis and } \\
\text { lymphoma }\end{array}$ & $\begin{array}{l}\text { Squamous cell } \\
\text { carcinoma } \\
\text { Kaposi's sarcoma } \\
\text { Primary ocular } \\
\text { lymphoma }\end{array}$ & $\begin{array}{l}\text { HIV microangiopathy: } \\
\text { Intraretinal haemorrhages } \\
\text { Cotton wool spots }\end{array}$ & $\begin{array}{l}\text { Immune recovery } \\
\text { uveitis (IRU) } \\
\text { Retinal detachment } \\
\text { Cataract } \\
\text { Macula oedema }\end{array}$ \\
\hline
\end{tabular}

Highly active antiretroviral therapy (HAART) consists of combination therapy: two nucleoside reverse transcriptase inhibitors and a protease inhibitor which result in substantial and sustained suppression of the HIV replication [HIV RNA viral load] (13). Highly active antiretroviral therapy has been successful in decreasing the mortality and morbidity of HIV patients (14-16). With the patient's immune recovery and increase in CD4 counts, opportunistic infections have a reduced frequency and less aggressive course $(17,18)$.

The odds ratio of developing eye problems in HIV patients with World Health Organization (WHO) clinical stage 3-4 was 9.4, compared to 1 for those with stage $1-2$ (5, visual problems (Fig. 1). Most HIV patients are referred for an eye examination when they have visual problems, therefore, the true incidence of HIV retinopathy may be underestimated. HIV retinal microangiopathy is significantly associated with mortality $[p=0.005]$ (22).

\section{Opportunistic infections}

Cytomegalovirus (CMV) retinitis is the most prevalent opportunistic infection occurring in AIDS patients (7, 8, 12, 23). Approximately $30 \%$ of patients with AIDS developed CMV retinitis before HAART $(16,24)$. The estimated lifetime cumulative incidence of CMV retinitis is $25-40 \%$ (7). 




Fig. 1: Cotton wool spots in HIV retinal microangiopathy.

Hodge et al looked at over 5200 person years of follow-up in HIV patients versus 30100 person years of follow-up in nonHIV patients to determine the incident relative risk of opportunistic infections in San Francisco (7). They found 790 cases of CMV retinitis amongst the HIV group and none in the non-HIV group, making the relative risk incidence of CMV retinitis infinite in the HIV group. The relative risk incidence of pneumocystis choroidopathy and ocular syphilis was also infinite, but the risk was much lower than that of CMV (7).

The relative risk of herpes zoster, fungal retinitis, toxoplasmosis retinitis and herpes simplex was 6.6:1, 4.9:1, 2.1:1 and 1.2:1, respectively (7). The incidence of toxoplasmosis retino-choroiditis $(11 \%)$, herpetic retinopathy $(1-3 \%)$, Pneumocystis jirovecii, tuberculous and cryptococcus choroiditis, syphilitic retinitis, and intraocular lymphoma is infrequent $(21,25)$. Even in the HAART era, fluconazole maintenance therapy is recommended $(200 \mathrm{mg} /$ day $)$ in all patients who have had cryptococcus infection (20).

\section{Cytomegalovirus retinitis}

The worldwide incidence of CMV retinitis (except in Africa) is $18-40 \%(21,25)$. The incidence of CMV retinitis in Africa is lower, 0-16.5\%; however, anterior segment findings: herpes zoster ophthalmicus (HZO) and squamous cell carcinoma (SCC), are more common there $(5,6,26-28)$. This may result from differences in race, HIV subtypes, comorbidity or early mortality from systemic opportunistic diseases before the CD4 count falls low enough for the opportunistic infections to occur $(5,27)$.

Cytomegalovirus enters the eye through the retinal blood vessels and is found in the vascular endothelial cells at the edge of the lesion. It causes full thickness retinal necrosis with associated haemorrhage (haemorrhagic retinitis otherwise called 'pizza pie' appearance) which spreads in a contiguous manner. It may uncommonly have an indolent progression with granular lesions in the peripheral retina.
Symptoms include floaters, visual field defects or visual loss, with macula involvement or retinal detachment [RD] (29). Retinal detachment occurs in $13-29 \%$ of patients, usually in the healing phase, and requires pars plana vitrectomy, endolaser and intraocular silicone oil to tamponade the retina (20). Since the advent of HAART, RDs have reduced by $60-80 \%$ $(20,25)$. The risk factors for developing RDs included a lower CD4 T cell count and larger CMV retinitis lesions (30). In the pre HAART era, the rate of RD in a CMV retinitis patient was $\sim 0.50$ /person years, but this has been decreased in the HAART era to $0.06 /$ person years (30). Second eye or contralateral involvement occurred via the haematogenous route and was a more frequent occurrence in the pre HAART era. For patients who were treated with an intravitreal injection of anti-CMV medication, their rate of contralateral eye disease was $0.1 /$ person year. This was reduced to 0.05 / person year if they received systemic anti-CMV drugs (30).

Cytomegalovirus produces cytokine homologues, eg interleukin 10, which inhibits Thelper type-1 (Th1), a key to cell mediated immunity. It also produces chemokine receptors, which inhibit inflammatory and immune cells by binding chemokine, which can accelerate the time from HIV to $\operatorname{AIDS}(31,32)$.

In the pre HAART era, the odds ratio for developing CMV retinitis in patients with baseline $\mathrm{CD} 4^{+}$lymphocyte counts of $0-50$ cells $/ \mu \mathrm{L}$ was $4.6(p=0.002)$ compared with patients with $\mathrm{CD}^{+}$lymphocyte counts of $101-250$ cells $/ \mu \mathrm{L}$ (33). Hamamotoo et al showed the average $\mathrm{CD}^{+} \mathrm{T}$-cell counts at diagnosis of CMV retinitis were $45.2 / \mu \mathrm{L}$ before and 116.7/ $\mu \mathrm{L}$ after HAART (34). Having a $\mathrm{CD}^{+} \mathrm{T}$ cell count $<$ 50 cells $/ \mu \mathrm{L}$ was the single most important risk factor $(p<$ 0.0001) for developing retinitis (35). In the present HAART era, the incidence of CMV retinitis in patients with AIDS is 0.36/100 person years (35). Despite HAART, patients with $<50 \mathrm{CD} 4 \mathrm{~T}$-cells $/ \mu \mathrm{L}$ have a similar risk of developing CMV retinitis as compared to the pre HAART era (36). Complications of CMV retinitis occurs in $39 \%$ of patients and include $\mathrm{RD}$, uveitis and optic atrophy, however, immune recovery uveitis (IRU) and cystoid macula oedema (CMO) are only seen in patients receiving HAART (23).

\section{Cytomegalovirus treatment}

Cytomegalovirus retinitis is treated with ganciclovir (intravenous or intravitreal implant) or oral valganciclovir, which has a very high oral bioavailability and good safety profile. Oral ganciclovir should not be used as it has 1/10 the bioavailability of oral valganciclovir. The pre HAART era required patients to have lifetime maintenance of these drugs, which have a risk of granulocytopenia, anaemia and thrombocytopenia. Selective discontinuation of anti-CMV treatment may be considered in HAART patients if the $\mathrm{CD} 4^{+} \mathrm{T}$ cell count is $>100$ cells $/ \mu \mathrm{L}$ for a minimum of three months or a 2-log unit or greater decrease in the HIV viral load (37). Deayton et al showed no CMV retinitis progression after six months of treatment in HAART patients over an eight-year 
period (23). A second line option includes foscarnet and cidofovir, however, these drugs can have severe side effects, including nephrotoxicity.

\section{Cytomegalovirus remission duration}

Patients who received HAART had a median CMV retinitis remission duration of 574 days, whereas those not on HAART had a median remission of 80.5 days [ $p<0.001]$ (70). The reduction in the viral load $(p=0.007)$ was a better clinical predictor for CMV retinitis remission versus the CD4 count $[p=0.058](38)$.

\section{Herpetic necrotizing retinopathy}

The herpes virus, varicella zoster, causes two clinical types of posterior segment inflammation: acute retinal necrosis (ARN) and progressive outer retinal necrosis (PORN). Acute retinal necrosis occurs in immunocompetent and AIDS patients with CD $<100$ cells/ $\mu \mathrm{L}$, but PORN occurs only in severely immunocompromised patients (21). Treatment of ARN is with intravenous acyclovir for one week then oral acyclovir for six weeks, or oral valacyclovir. Prophylactic laser photocoagulation would be required to prevent a retinal detachment. Progressive outer retinal necrosis is a very aggressive retinitis which results in $>30 \%$ of patients going blind, and requires intravitreal ganciclovir injections and intravenous treatment $(39,40)$.

\section{Immune recovery uveitis}

Immune recovery uveitis (IRU) is part of the immune recovery inflammatory syndrome (IRIS) which is associated with immune reconstitution in organs with opportunistic infections such as mycobacteria, CMV, cryptococcal, toxoplasmosis and Pneumocystis jirovecii pneumonia (41). Patients develop IRIS within four to eight weeks of starting HAART and have high viral loads and low CD4 T lymphocyte count. Due to immune reconstitution on HAART, patients have a stronger immunological response to infections, resulting in inflammation (uveitis or vitritis) which is deleterious to the eye. The diagnosis may be equivocal, as it must be differentiated from progression of the infection, antimicrobial resistance, treatment failure, organ dysfunction or drug toxicity $(41,42)$.

Immune recovery uveitis did not occur prior to HAART and has had increasing incidence since its implementation (34). Immune recovery uveitis occurs in $0.12-$ 0.8 cases per person year (42). It is seen in $14-16.9 \%$ of patients recovering from CMV retinitis, resulting in $\mathrm{CMO}$, a cause of visual loss amongst IRU patients (8, 43-45). Cidofovir, an acyclic nucleotide analogue used in the treatment of CMV, had a 3.3 times greater risk of developing IRU versus an alternative treatment $[p=0.4]$ (46). Treatment is with corticosteroids and discontinuing the drug.

The timing of commencing HAART in patients with active CMV retinitis is important to their clinical progress (47). If HAART is started before the two-week induction of
CMV therapy is completed, $71 \%$ of patients develop an IRU. However, if started after induction and suppression of retinitis, the incidence of IRU reduces to $31 \%$ (47). However, this is specific to $\mathrm{CMV}$, as the vitritis can cause serious problems such as further retinal necrosis, RD, cataract and glaucoma. Zolopa et al proved that early commencement of antiretroviral therapy for opportunistic infections such as Pneumocystis jirovecii pneumonia, cryptococcal meningitis and bacterial infections results in fewer AIDS progression and death (37).

\section{Other infections}

In an African study, 96\% of patients with tuberculosis (TB) presenting to a hospital with fever had HIV; of these, $2.8 \%$ had choroidal granulomas (27). In Southeast Asia, the prevalence of Toxoplasma gondii antibody is similar in HIVpositive (23.2\%) versus HIV-negative patients [29.5\%] (48). Brazil has a high incidence of ocular toxoplasmosis occurring in $8.5 \%$ of patients, whereas CMV retinitis is seen in $25 \%$ of cases (49). Toxoplasma is more likely to present as toxoplasma encephalitis than ocular disease (50). The incidence of the opportunistic infections and ocular signs vary geographically.

Molluscum contagiosum, discrete, elevated, pearly white umbilicated lesions of the eyelids can be a presenting ocular feature of HIV disease (50). It occurs in $1 \%$ of HIV patients, with extensive dissemination and an aggressive course compared to its normal appearance $(9,51)$. Treatment options include incision and curettage, liquid nitrogen, trichloroacetic acid or cryotherapy. However, patients on HAART may undergo spontaneous resolution of Molluscum contagiosum within six months $(52,53)$.

Microsporidia, an obligate intracellular protozoan parasite was first reported in an HIV-positive patient in 1985 (54). Prior to this, only 10 cases had been reported in humans, but in the first decade of the HIV epidemic there were more than 400 reported cases in HIV patients (55). It presents as keratoconjunctivitis and is diagnosed by conjunctival scraping or biopsy. Commencement on HAART has been shown to lead to resolution of the keratoconjunctivitis (56).

\section{Ocular inflammation secondary to drugs}

Rifabutin is a rifamycin derivative used for treatment and prophylaxis against Mycobacteria avium complex (MAC) infections in HIV patients (42). At doses of 300-1800 $\mathrm{gm} /$ day, it may cause a unilateral or bilateral anterior uveitis, vitritis and retinal vasculitis which is dose related. The severity may result in a hypopyon (pus in the anterior chamber of the eye), two to seven months after initiating treatment $(42,57-60)$. The risk increases with concurrent use of protease inhibitors (part of HAART); the mechanism of action is unknown and treatment may be with corticosteroids, reducing or discontinuing the drug (42, 57-59). Rifabutin may also cause stellate corneal endothelial deposits 
in $18 \%$ of patients (61). It is important that pulmonologists and ophthalmologists are aware of the induced uveitis, so that patients are referred early for management.

\section{Neuro-ophthalmic features}

Neuro-ophthalmic manifestations may involve the afferent and extraocular pathways, resulting in visual loss, visual field defects or extraocular motility disorders. Neuro-ophthalmic problems may occur in up to $50 \%$ of HIV patients with 75 $90 \%$ of patients having histologic evidence of brain or optic nerve involvement $(62,63)$.

Optic neuropathy occurs in HIV due to an infectious, compressive, inflammatory or infiltrative process. The HIV DNA is more commonly found in the optic nerve than retina (4:1), and the resulting degenerative change is secondary to HIV infected macrophages instead of direct viral infection (63). Visual evoked potential (VEP) was reduced in 57\% and $42 \%$ of patients with and without neurological dysfunction, which supports the hypothesis of axonal loss occurring in HIV positive patients regardless of neurological symptoms (62). Patients may present with sub-acute bilateral painless optic neuropathy, for which antiretrovirals and corticosteroids are of no benefit, as it is due to microvascular ischaemia of the optic nerve head (64). This can lead to optic atrophy (Fig. 2). Cryptococcus neoformans is the most likely cause

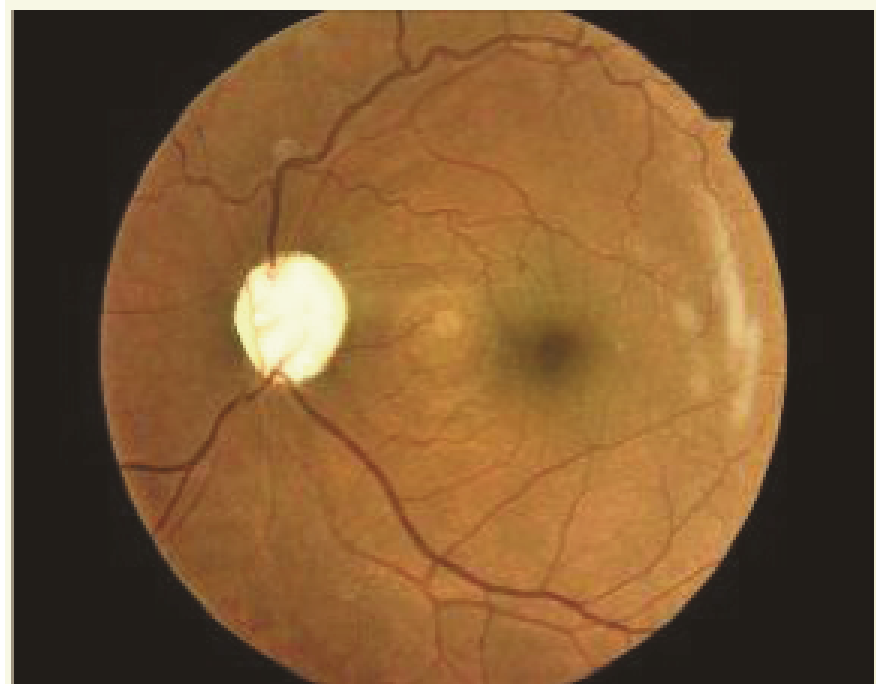

Fig. 2: Optic atrophy.

of optic disc swelling and may be associated with meningitis (65). With the use of HAART, IRIS may occur and $50 \%$ may lose vision because of raised intracranial pressure (65).

Eighty-six per cent of patients with neuro-ophthalmic disorders in AIDS have extra ocular motility disorders; palsies of the $3^{\text {rd }}$ and $6^{\text {th }}$ nerve, being most common, are usually secondary to toxoplasmosis and cryptococcosis meningitis (62). The prevalence of toxoplasma encephalitis has reduced with HAART, from $5.7 \%$ to $2.2 \%[p=0.015]$ (66). Homonymous hemianopia can be a presenting sign of HIV, due to a cerebral abscess secondary to TB or opportunistic infection associated meningitis (67).

\section{Unusual malignancies}

Oculocutaneous Kaposi's sarcoma (KS), an AIDS defining disease, may occur in the conjunctiva or eyelids as a flat or elevated bluish purple lesion $(2,42)$. It occurs in $9 \%$ of HIV patients and may be mistaken for a subconjunctival haemorrhage, pyogenic granuloma or lymphangioma $(42,68)$. Ocular KS may be treated if eyelid function is affected or for cosmesis (42). The treatment options include radiation, excision, cryotherapy, chemotherapy (bleomycin, doxorubicin, vinblastine) or subconjunctival interferon alpha2a; however, recurrence and progression can occur despite treatment (42, 69). With HAART, the treatment results vary. In Italy, there was $91 \%$ remission with HAART treatment, with complete remission occurring over five years, associated with significant CD4 cell count increase and decrease in HIV-1 RNA copies (70). Dupoint et al, in a Paris study, noted complete remission in $52.6 \%$ patients on HAART, even without specific KS treatment; this may be due to improvement in the immune status (71).

Squamous cell carcinoma (SCC) is seen mainly in subSaharan Africa, occurring in $3.8-7.8 \%$ of HIV patients. It presents at an earlier age and is more aggressive in HIV patients (72). Squamous cell carcinoma was the initial manifestation of HIV in $79 \%$ of patients in Malawi (73). It is uncommon in Europe and Australia (74). Squamous cell carcinoma typically occurs on the eyelids or conjunctiva, where it may be mistaken for a pterygium. It has been seen in the Jamaican population. The male to female ratio is 1.7:1 with a mean age of 40 years (26). Squamous cell carcinoma of the conjunctiva can be aggressive, requiring enucleation or exenteration (removal of the eye and all the orbital contents) or it may be treated with topical interferon alpha $2 \mathrm{~b}$ to prevent recurrence (75). Highly active antiretroviral therapy has not shown a reduction of incidence in AIDs defining head and neck cancers $(74,76)$.

Non-Hodgkin's lymphoma is the second most common opportunistic neoplasm in HIV infection, accounting for 3.5$5 \%$ of AIDS defining illnesses patients. Ocular involvement may occur in the adnexae with eyelid masses or infiltrate the orbit resulting in a painful proptosis. Primary intraocular lymphoma (PIL) is rare (7). Typically intraocular lymphoma presents as a unilateral or bilateral vitritis unresponsive to corticosteroids. Vitreous biopsy is essential for diagnosis. Since HAART, the incidence of Non-Hodgkin's lymphoma in HIV patients has reduced, but the effect on PIL has not been studied. There has been a case report of an HIVpositive patient who presented with an intraocular B cell lymphoma (CD4 count of 44 cells $/ \mu \mathrm{L})$ in a blind eye, and was treated with radiotherapy and chemotherapy. However, three years later he represented with a conjunctival SCC in the same eye; the HIV patient is at risk of multiple cancers (77). 


\section{Causes of visual loss in HIV patients}

In the pre HAART era, maculopathy (from extension of CMV retinitis) was the primary cause for visual loss of $20 / 200$ or worse $(\leq 20 / 200)$ in $84 \%$ of AIDS patients, with $\mathrm{RD}$ being the second most common cause [36-63\%] (29). In the post HAART era, it still remains the leading cause in $69.8 \%$ of cases. However, in the HAART era, cataract has become the second most common cause of visual loss, occurring in $28.6 \%$; retinal detachment is third at $16.7 \%$ and macula oedema, which was $<5 \%$ pre HAART, is now the fourth most common cause of visual loss in $11.1 \%$ of cases (29). In the Studies of the Ocular Complications of AIDS (SOCA), they assessed the ocular examination of patients at the time of diagnosis and found that cataract was more common in HIV/AIDS patients compared to age-matched norms (78). However, RD still gives the highest risk of visual loss with $42 \%$ of patients developing legal blindness (> 20/200) despite surgery. Cataract on the other hand, is a cause of reversible blindness.

\section{CONCLUSION}

Highly active antiretroviral therapy has reduced the incidence of opportunistic infections, increased the time of remission, reduced the complications of CMV and has allowed the discontinuation of anti-CMV medications and the spontaneous regression of Kaposi's sarcoma. It has changed the face of HIV-related eye disease with respect to new complications with CMV as with immune recovery uveitis, cystoid macula oedema and cataract. Blepharitis and keratoconjunctivitis are now the commonest ocular features of HIV in the HAART era in Brazil, but cytomegalovirus remains the most prevalent OI (11).

In the Caribbean, there is a reported $54.8-70.1 \%$ adherence to taking antiretroviral therapy and a $6 \%$ resistance to the drug therapy $(79,80)$. In Jamaica, $4.7 \%$ of patients have opportunistic infections and we have shown an improvement in CD4 count with antiretroviral therapy, but studies are yet to be done to look at the reduction of ocular morbidity with HAART in the West Indies $(81,82)$.

\section{REFERENCES}

1. Holland GN, Gottlieb MS, Schanker HM, Pettit TH. Ocular disorders associated with a new severe acquired cellular immunodeficiency syndrome. Am J Ophthalmol 1982; 93: 393-402.

2. Holland GN, Pepose JS, Pettit TH, Gottlieb MS, Yee RD, Foos RY. Acquired immune deficiency syndrome. Ocular manifestations. Ophthalmology 1983; 90: 859-73.

3. Holland GN, Gottlieb MS, Foos RY. Retinal cotton-wool patches in acquired immunodeficiency syndrome. N Engl J Med 1982, 307: 1704.

4. Biswas J, Madhavan HN, George AE, Kumarasmy N, Solomon S. Ocular lesions associated with HIV infection in India: a series of 100 consecutive patients evaluated at a referral centre. Am J Ophthalmol 2000; 129: 9-15.

5. Pathai S, Deshpande A, Gilbert C, Lawn S. Prevalence of HIV-associated ophthalmic disease among patients enrolling for antiretroviral treatment in India: a cross-sectional study. BMC Infect Dis 2009; 9: 158. E-pub 2009 September 23. doi: 10.1186/1471-2334-9-158.

6. Sahoo S. HIV- and AIDS-related ocular manifestations in Tanzanian patients. Malays J Med Sci 2010; 17: 12-6.
7. Hodge WG, Seiff SR, Margolis TP. Ocular opportunistic infection incidences among patients who are HIV positive compared to patients who are HIV negative. Ophthalmology 1998; 105: 895-900.

8. Wang Z, Jia R, Ge S, He T, Zhang Y, Yang Y et al. Ocular complications of human immunodeficiency virus infection in Eastern China. Am J Ophthalmol 2012; 153: 363-9.

9. Kim SJ, Park SJ, Yu HG, Kim NJ, Jang HC, Oh MD. Ocular manifestations of acquired immunodeficiency syndrome in Korea. Korean Med Sci 2012; 27: 542-6.

10. Belfort R, Muccioli C. Experience of HIV/AIDS and the eye in Brazil, South America. Community Eye Health 1995; 8: 26-7.

11. Rodrigues ML, Rodrigues M de L, Figueiredo JF, de Freitas JA. Ocular problems in Brazilian patients with AIDS before and in highly active antiretroviral therapy (HAART) era. Braz J Infect Dis 2007; 11: 199202.

12. Vrabec TR. Posterior segment manifestations of HIV/AIDS. Surv Ophthalmol 2004; 49: 131-57.

13. Hammer SM, Eron JJ Jr, Reiss P, Schooley RT, Thompson MA, Walmsley S et al. Antiretroviral treatment of adult HIV infection: 2008 recommendations of the International AIDS Society - USA panel. JAMA 2008; 300: 555-70. doi: 10.1001/jama.300.5.555.

14. Grabar S, Le Moing V, Goujard C, Leport C, Kazatchkine MD, Costagliola D et al. Clinical outcomes of patients with HIV-1 infection according to immunologic and virologic response after 6 months of highly active antiretroviral therapy. Ann Intern Med 2000; 133: 401-10.

15. Murphy EL, Collier AC, Kalish LA, Assmann SF, Para MF, Flanigan TP et al. Highly active antiretroviral therapy decreases mortality and morbidity in patient with advanced HIV disease. Ann Intern Med 2001; 135: 17-26.

16. Palella FJ Jr, Delaney KM, Moorman AC, Loveless MO, Fuhrer J, Satten GA et al. Declining morbidity and mortality among patients with advanced human immunodeficiency virus infection. HIV Outpatient Study Investigators. N Engl J Med 1998; 338: 853-60.

17. Doan S, Cochereau I, Guvenisik N, Diraison MC, Mousalatti H, Thanh HX. Cytomegalovirus retinitis in HIV infected patients with and without highly active antiretroviral therapy. Am J Ophthalmol 1999; 128: 250-1.

18. Macdonald JC, Karavellas MP, Torriani FJ, Morse LS, Smith IL, Reed $\mathrm{JB}$ et al. Highly active antiretroviral therapy-related immune recovery in AIDS patients with cytomegalovirus retinitis. Ophthalmology 2000; 107: $877-83$.

19. World Health Organization. Interim WHO clinical staging of HIV/ AIDS and HIV/AIDS case definitions for surveillance. African region. 2005 [cited 2012 Dec 27]. Available from: http://www.who.int/hiv/pub/ guidelines/clinicalstaging.pdf

20. Banker AS. Posterior segment manifestations of human immunodeficiency virus/acquired immune deficiency syndrome. Indian J Ophthalmol 2008; 56: 377-83.

21. Arruda RF, Muccioli C, Belfort R Jr. Ophthalmological findings in HIV infected patients in the post-HAART (highly active anti-retroviral therapy) era, compared to the pre-HAART era. Rev Assoc Med Bras 2004; 50: 148-52.

22. Lai TY, Wong RL, Luk FO, Chow VW, Chan CK, Lam DS. Ophthalmic manifestations and risk factors for mortality of HIV patients in the posthighly active anti-retroviral therapy era. Clin Experiment Ophthalmol 2011; 39: 99-104.

23. Deayton JR, Wilson P, Sabin CA, Davey CC, Johnson MA, Emery VC et al. Changes in the natural history of cytomegalovirus disease following the introduction of highly active antiretroviral therapy. AIDS 2000; 14: 1163-70.

24. Varani S, Spezzacatena P, Manfredi R, Chiodo F, Mastroianni A, Ballarini P et al. The incidence of cytomegalovirus (CMV) antigenemia and CMV disease is reduced by highly active antiretroviral therapy. Eur J Epidemiol 2000; 16: 433-7.

25. Goldberg DE, Smithen LM, Angelilli A, Freeman WR. HIV-associated retinopathy in the HAART era. Retina 2005; 25: 633-49.

26. Onakoya AO, Odeyemi MG, Aribaba OT, Akinsola FB. Ocular findings in acquired immunodeficiency syndrome patients in Lagos, Nigeria. Nig Q J Hosp Med 2012; 22: 52-7. 
27. Beare NAV, Kublin JG, Lewis DK, Schijffelen MJ, Peters RPH, Joaki $\mathrm{G}$ et al. Ocular disease in patients with tuberculosis and HIV presenting with fever in Africa. Br J Ophthalmol 2002; 86: 1076-9.

28. Nkomazana O, Tshitswana D. Ocular complications of HIV infection in sub-Sahara Africa. Curr HIV/AIDS Rep 2008; 5: 120.

29. Thorne JE, Jabs DA, Kempen JH, Holbrook JT, Nichols C, Meinert CL et al. Causes of visual acuity loss among patients with AIDS and cytomegalovirus retinitis in the era of highly active antiretroviral therapy. Ophthalmology 2006; 113: 1441-5.

30. Jabs DA, Van Natta ML, Thorne JE, Weinberg DV, Meredith TA, Kuppermann BD et al. Course of cytomegaloviris retinitis in the era of highly active antiretroviral therapy: 2. Second eye involvement and retinal detachment. Ophthalmology 2004; 111: 2232-9.

30. Jabs DA. Cytomegalovirus retinitis and the acquired immunodeficiency syndrome - bench to bedside: LXVII Edward Jackson Memorial Lecture. Am J Ophthalmol 2011; 151: 198-216.

31. Sabin CA, Phillips AN, Lee CA, Janossy G, Emery V, Griffiths PD. The effect of CMV infection on progression of human immunodeficiency virus disease is a cohort of haemophilic men followed for up to 13 years from seroconversion. Epidemiol Infect 1995; 114: 361-72.

32. Pertel P, Hirschtick R, Phair J, Chmiel J, Poggensee L, Murphy R. Risk of developing cytomegalovirus retinitis in persons infected with the human immunodeficiency virus. J Acquir Immune Defic Syndr 1992; 5: 1069-74.

33. Hamamotoo A, Tatebayashi M, Uehira A, Kuroda S, Morimoto Y, Nakagawa $\mathrm{T}$ et al. Retrospective study of ocular complications in patients with human immunodeficiency virus infection before and after HAART. Nihon Ganka Gakkai Zasshi 2012; 116: 721-9.

34. Sugar EA, Jabs DA, Ahuja A, Thorne JE, Danis RP, Meinert CL et al. Incidence of cytomegalovirus retinitis in the era of highly active antiretroviral therapy. Am J Ophthalmol 2012; 153: 1016-24.

35. Butler NJ, Thorne JE. Status of HIV infection and ocular disease. Curr Opin Ophthalmol 2012; 23: 517-22.

36. Zolopa A, Andersen J, Powderly W, Sanchez A, Sanne I, Suckow C et al. Early antiretroviral therapy reduces AIDS progression/death in individuals with acute opportunistic infections: a multicenter randomized strategy trial. PLoS One 2009; 4: e5575.

37. Lin DY, Warren JF, Lazzeroni LC, Wolitz RA, Mansour SE. Cytomegalovirus retinitis after initiation of highly active antiretroviral therapy in HIV infected patients: natural history and clinical predictors. Retina 2002; 22: 268-77.

38. Yin PD, Kurup SK, Fischer SH, Rhee HH, Byrnes GA, Levy-Clarke GA et al. Progressive outer retinal necrosis in the era of highly active antiretroviral therapy: successful management with intravitreal injections and monitoring with quantitative PCR. J Clin Virol 2007; 38: 254-9.

39. Gore DM, Gore SK, Visser L. Progressive outer retinal necrosis: outcomes in the intravitreal era. Arch Ophthalmol 2012; 130: 700-6.

40. Kaplan JE, Benson C, Holmes KH, Brooks JT, Pau A, Masur H et al. Guidelines for prevention and treatment of opportunistic infections in HIV-infected adults and adolescents: recommendations from CDC, the National Institutes of Health, and the HIV Medicine Association of the Infectious Diseases Society of America. MMWR Recomm Rep 2009; 58: $1-207$.

41. Jeng BH, Holland GN, Lowder CY, Deegan WF 3rd, Raizman MB, Meisler DM. Anterior segment and external ocular disorders associated with human immunodeficiency virus disease. Surv Ophthalmol 2007; 52: 329-68.

42. Alp MN, Baykam N, Kural G. Immune recovery uveitis associated with highly active antiretroviral therapy in a patient with CMV retinitis and AIDS despite a low CD4+ T cell count: case report and a review of the literature. Int Ophthalmol 2010; 30: 183-9.

43. Guzak R, Rodman J, Pizzimenti J. Cystoid macular edema as a result of immune-recovery uveitis. Optom Vis Sci 2011; 88: E344-51.

44. Kempen JH, Min YI, Freeman WR, Holland GN, Friedberg DN, Dieterich DT et al. Risk of immune recovery uveitis in patients with AIDS and cytomegalovirus retinitis. Ophthalmology 2006; 113: 684 94
45. Song MK, Azen SP, Buley A, Torriani F, Cheng L, Chaidhawangul S et al. Effect of anti-cytomegalovirus therapy on the incidence of immune recovery uveitis in AIDS patients with healed cytomegalovirus retinitis. Am J Ophthalmol 2003; 136: 696-702.

46. Ortega-Larrocea G, Espinosa E, Reyes-Terán G. Lower incidence and severity of cytomegalovirus-associated immune recovery uveitis in HIV-infected patients with delayed highly active antiretroviral therapy. AIDS 2005; 19: 735-8.

47. Sukthana Y, Chintana T, Lekkla A. Toxoplasma gondii antibody in HIV infected persons. J Med Assoc Thai 2000; 83: 681-4.

48. Hoffmann C, Ernst M, Meyer P, Wolf E, Rosenkranz T, Plettenberg A et al. Evolving characteristics of toxoplasmosis in patients infected with human immunodeficiency virus-1: clinical course and Toxoplasma gondii-specific immune responses. Clin Microbiol Infect 2007; 13: $510-5$.

49. Leahey AB, Shane JJ, Listhaus A, Trachtman M. Molluscum contagiosum eyelid lesions as the initial manifestation of acquired immunodeficiency syndrome. Am J Ophthalmol 1997; 124: 240-1.

50. Robinson MR, Udell IJ, Garber PF, Perry HD, Streeten BW. Molluscum contagiosum of the eyelids in patients with acquired immune deficiency syndrome. Ophthalmology 1992; 99: 1745-7.

51. Calista D, Boschini A, Landi G. Resolution of disseminated Molluscum contagiosum with highly active anti-retroviral therapy (HAART) in patients with AIDS. Eur J Dermatol 1999; 9: 211-3.

52. Schulz D, Sarra GM, Koerner UB, Garweg JG. Evolution of HIV-1related conjunctival Molluscum contagiosum under HAART: report of a bilaterally manifesting case and literature review. Graefes Arch Clin Exp Ophthalmol 2004; 242: 951-5.

53. Modigliani R, Bories C, Le Charpentier Y, Salmeron M, Messing B, Galian A et al. Diarrhoea and malabsorption in acquired immune deficiency syndrome: a study of four cases with special emphasis on opportunistic protozoan infestations. Gut 1985; 26: 179-87.

54. Bryan RT. Microsporidiosis as an AIDS-related opportunistic infection. Clin Infect Dis 1995; 21 (Suppl): 62-5.

55. Martins SA, Muccioli C, Belfort R Jr, Castelo A. Resolution of microsporidial keratoconjunctivitis in an AIDS patient treated with highly active antiretroviral therapy. Am J Ophthalmol 2001; 131: 378-9.

56. Bazewicz M, Fikri J, Martin CH, Libois A, Meunier A, Frippiat F et al. Drug-induced uveitis in AIDS patients: two case reports. Bull Soc Belge Ophtalmol 2011; 318: 19-23

57. Ishiguchi N, Ueno K, Yanagihara M, Kadono K, Oshika T. Rifabutinassociated hypopyon uveitis in patient with acquired immunodeficiency syndrome. Nihon Ganka Gakkai Zasshi 2010; 114: 683-6.

58. Wang HH, Chung YM, Lin YC, Hu HC, Wong WW. Rifabutin-induced hypopyon uveitis in patients with acquired immunodeficiency syndrome infected with Mycobacterium avium complex. J Chin Med Assoc 2007; 70: 136-9.

59. Arevalo JF, Russack V, Freeman WR. New ophthalmic manifestations of presumed rifabutin-related uveitis. Ophthalmic Surg Lasers 1997; 28: $321-4$.

60. Smith JA, Mueller BU, Nussenblatt RB, Whitcup SM. Corneal endothelial deposits in children positive for human immunodeficiency virus receiving rifabutin prophylaxis for Mycobacterium avium complex bacteremia. Am J Ophthalmol 1999; 127: 164-9.

61. Mwanza JC, Nyamabo LK, Tylleskär T, Plant GT. Neuro-ophthalmological disorders in HIV infected subjects with neurological manifestations. Br J Ophthalmol 2004; 88: 1455-9.

62. Sadun AA, Pepose JS, Madigan MC, Laycock KA, Tenhula WN, Freeman WR. AIDS-related optic neuropathy: a histological, virological and ultrastructural study. Graefes Arch Clin Exp Ophthalmol 1995; 233: 387-98.

63. Laurent-Coriat C, Tilikete C, Bouhour D, Boulliat J, Fleury J, Bernard $\mathrm{M}$ et al. HIV infection presenting with bilateral optic neuropathy. Rev Neurol (Paris) 2006; 162: 95-7.

64. Khurana RN, Javaheri M, Rao N. Ophthalmic manifestations of immune reconstitution inflammatory syndrome associated with Cryptococcus neoformans. Ocul Immunol Inflamm 2008; 16: 185-90. 
65. Maschke M, Kastrup O, Esser S, Ross B, Hengge U, Hufnagel A. Incidence and prevalence of neurological disorders associated with HIV since the introduction of highly active antiretroviral therapy (HAART). J Neurol Neurosurg Psychiatry 2000; 69: 376-80.

66. Gharai S, Venkatesh P, Sinha A, Garg S, Ghosh P. Isolated homonymous hemianopsia due to presumptive cerebral tubercular abscess as the initial manifestation of human immunodeficiency virus infection. Indian J Ophthalmol 2012; 60: 321-4.

67. Pepose JS, Holland GN, Nestor MS, Cochran AJ, Foos RY. Acquired immune deficiency syndrome; pathogenic mechanisms of ocular disease. Ophthalmology 1985; 92: 472-84.

68. Shuler JD, Holland GN, Miles SA, Miller BJ, Grossman I. Kaposi sarcoma of the conjunctiva and eyelids associated with the acquired immunodeficiency syndrome. Arch Ophthalmol 1989; 107: 858-62.

69. Cattelan AM, Calabrò ML, De Rossi A, Aversa SM, Barbierato M, Trevenzoli $\mathrm{M}$ et al. Long-term clinical outcome of AIDS-related Kaposi's sarcoma during highly active antiretroviral therapy. Int $\mathrm{J}$ Oncol 2005; 27: 779-85.

70. Dupont C, Vasseur E, Beauchet A, Aegerter P, Berthé H, de Truchis P et al. Long-term efficacy on Kaposi's sarcoma of highly active antiretroviral therapy in a cohort of HIV-positive patients. CISIH 92. Centre d'information et de soins de l'immunodéficience humaine. AIDS 2000; 14: $987-93$.

71. Nagaiah G, Stotler C, Orem J, Mwanda WO, Remick SC. Ocular surface squamous neoplasia in patients with HIV infection in sub-Saharan Africa. Curr Opin Oncol 2010; 22: 437-42.

72. Spitzer MS, Batumba NH, Chirambo T, Bartz-Schmidt KU, Kayange P, Kalua $\mathrm{K}$ et al. Ocular surface squamous neoplasia as the first apparent manifestation of HIV infection in Malawi. Clin Experiment Ophthalmol 2008; 36: 422-5.
73. Purgina B, Pantanowitz L, Seethala RR. A review of carcinomas arising in the head and neck region in HIV-positive patients. Patholog Res Int 2011; 2011: 469150. doi: 10.4061/2011/469150. Epub 2011 May 10.

74. Shields CL, Ramasubramanian A, Mellen PL, Shields JA. Conjunctival squamous cell carcinoma arising in immunosuppressed patients (organ transplant, human immunodeficiency virus infection). Ophthalmology 2011; 118: 2133-7.

75. Cheung MC, Pantanowitz L, Dezube BJ. AIDS-related malignancies: emerging challenges in the era of highly active antiretroviral therapy. Oncologist 2005; 10: 412-26.

76. Babu K, Murthy KR, Krishnakumar S. Two successive ocular malignancies in the same eye of a HIV-positive patient: a case report. Ocul Immunol Inflamm 2010; 18: 101-3.

77. Jabs DA, Van Natta ML, Holbrook JT, Kempen JH, Meinert CL, Davis MD et al. Longitudinal study of the ocular complications of AIDS: 2. Ocular examination results at enrollment. Ophthalmology 2007; 114: 787-93.

78. Allen CF, Simon Y, Edwards J, Simeon DT. Adherence to antiretroviral therapy by people accessing services from non-governmental HIV support organizations in three Caribbean countries. West Indian Med J 2011; 60: 269-75.

79. Harvey KM, Carrington D, Duncan J, Figueroa JP, Hirschorn L, Manning D et al. Evaluation of adherence to highly active antiretroviral therapy in adults in Jamaica. West Indian Med J 2008; 57: 293-7.

80. Clarke TR, Barrow G, Thompson D, Gibson R, Barton EN. Response to first line HAART using CD4 cell counts: experience in a university hospital in Kingston. West Indian Med J 2010; 59: 439-44.

81. Barrow G, Clarke TR, Carrington D, Harvey K, Barton EN. An analysis of three opportunistic infections in an outpatient HIV clinic in Jamaica. West Indian Med J 2010; 59: 393-9. 